Vol. 6, n 1 | 2002

Varia

\title{
Rawlings, Philip, Policing: A Short History
}

Willan Publishing (Policing and Society Series), Devon, 2002, 274 pp.

ISBN 1903240263

Robert M. Morris

\section{(2) OpenEdition}

1 Journals

Electronic version

URL: https://journals.openedition.org/chs/256

DOI: $10.4000 /$ chs. 256

ISSN: 1663-4837

Publisher

Librairie Droz

\section{Printed version}

Date of publication: 1 July 2002

Number of pages: 135-136

ISBN: 2-600-00803-9

ISSN: 1422-0857

\section{Electronic reference}

Robert M. Morris, "Rawlings, Philip, Policing: A Short History", Crime, Histoire \& Sociétés / Crime, History \& Societies [Online], Vol. 6, $n^{\circ} 1$ | 2002, Online since 28 April 2009, connection on 22 March 2022. URL:

http://journals.openedition.org/chs/256 ; DOI: https://doi.org/10.4000/chs.256

This text was automatically generated on 22 March 2022.

(c) Droz 


\section{Rawlings, Philip, Policing: A Short History}

Willan Publishing (Policing and Society Series), Devon, 2002, 274 pp. ISBN 1903240263

Robert M. Morris

\section{REFERENCES}

Rawlings, Philip, Policing: A Short History. Willan Publishing (Policing and Society Series), Devon, 2002, 274 pp. ISBN 1903240263.

1 Assimilating recent writing on police history and re-presenting it intelligibly is a bold enterprise. The author, a member of Warwick University Law School, has an established record of eclectic summary in relation to the history of prisons and criminal justice. The formidable bibliography listed in the current work indicates both how far academic interest in policing has grown in the last 40 years, and explains the opportunity accordingly available for the work of stock-taking represented by this book.

2 The book is also a first. Others have attempted general histories of policing in England from post-Roman times, but they have all been amateurs. Melville Lee, writing in 1901, was formerly a soldier and an unsuccessful aspirant for a senior police appointment. Charles Reith, writing during and on both sides of World War II, had been a tea planter. Tom Critchley, who in 1967 wrote the last published general history, was a civil servant who had been secretary to the Willink Royal Commission earlier that decade (The writer of this review comes from the same stable).

3 In his introduction, the author claims «The establishment of the Metropolitan Police in 1829 has transfixed historians of the police.» After a not always kind account of some of the earlier historiography, he explains that the book is «an attempt to use the idea of policing as a route into the state's involvement in policing; to consider questions such as, what shaped that involvement, its objectives and methods, and how these have 
changed». The main chapters cover the periods 600-1400 («From blood feud to the justice of the peace»); 1400-1600 («Policing the poor and the bureaucratization of policing»); 1660-1800 («The professionalization of policing»); 1800-1850 («The Jenny Darbies: the New Police»); 1850-1939 («'In the midst of hordes of starving plunderers'»); 1939-2001 («'The Foundations of law and order'»); and a short, final overview «The long history of policing».

4 Fiercely diligent, copiously footnoted (262 notes for the 1660-1800 chapter of 36 pages), what are the book's essential contributions? First, it is undoubtedly a feat of useful citation and reference. Anyone who wants to catch up on what academia in the (English speaking) field has been up to in the last forty or so years could hardly be better served than by the bibliography where W.R.Miller's «Cops andBobbies» (Chicago UP, 1977; recent reprint by Ohio State UP) and possibly F.W.Maitland's «Justice and Police» (London, 1885) seem the only significant omissions. Secondly, it offers an energetic narrative account of policing in England. Thirdly, its final arguments are powerful viz. that the bureaucratization of policing has proceeded on a false premise of police professional exclusivity which is unable by itself to deliver the range of policing services society in fact needs. That penny is dropping even now with British politicians who, if they read at all, could find in the book much of relevant interest to modern policy making.

5 All these are substantial merits and well worth having. At the same time, how successful is the author in circumventing the notorious problems involved in covering such a long period and its burgeoning literature? Not surprisingly, the outcome is perhaps unavoidably - patchy. Even though he wrote 100 years ago, it is not perhaps easy to say in principle all that much more than Melville Lee about the early medieval period. In the absence of anything else, the account of the mechanisms of blood feud and societal cohesion depend on extrapolation from anthropology. Well over half the book is in fact concerned with post 1829. The drive to leave no reference out imparts a hurried, hectic air. Coverage of the most recent period, particularly, rushes through events.

6 The result is a feeling that, although cited in abundance, the work of others may not have been wholly digested. Not found by this reader, for example, is the reflective depth and social understanding as well as the original research apparent in Clive Emsley's «The English Police» (London, 1996), although the latter limits itself to a smaller timeframe. An important, ground-breaking monograph like P. King's «Crime, Justice, and Discretion in England 1740-1820» (Oxford, 2000) is pressed into service only for scattered references (for example, at pages 76,80 and 124) and its essential challenge to earlier theses - emanating, it so happens, from a different part of Warwick University - does not surface at all. There are times when it is possible that the author has become so fixed on marshalling the work of others that he has not allowed himself the space to stand back from his material or be more critical. For example, it could be argued that, in one chapter, contemporary allegations about militarization are bought too easily ( $\mathrm{p}$. 120); that insufficient importance is attributed to the inauguration of central government funding from 1833 (p. 123); that the generalisations of three hundred years of development essayed at the top of p. 125 are particularly breathless; and that the 1856 Police Act should receive rather more attention even if it is no longer held to be quite as important as hitherto. Almost inevitably there are some factual errors. In another chapter, for example, we cannot be quite so sure about Mme D'Angely's bona 
fides as suggested on p. 160; it was Childers not Matthews who appointed Warren as Metropolitan Commissioner in 1886 (p. 165); and Colonel Feilding's name is misspelled (p. 173).

7 The latter are, of course, minor points and they should not be allowed to obscure the book's real achievements. If not exactly a short history as its title claims, it packs in a very great deal without being an unmanageable tome. As the first attempt since Critchley to tackle the whole of the history of English policing, it demonstrates the great advances made in the study of policing history, and will clearly stand as an important work of reference for anyone - professional or amateur - approaching the subject for the first time.

\section{AUTHORS}

\section{ROBERT M. MORRIS}

Open University (Milton Keynes, UK), (bob.morris@eggconnect.net) 